\title{
4-6 METŲ VAIKŲ MOTORINIŲ GEBĖJIMŲ IR KOGNITYVINIŲ FUNKCIJŲ SĄSAJA SU KÜDIKYSTĖS BENDROSIOS MOTORIKOS ROPOJIMO FUNKCIJA
}

\author{
Silvija Urvikytė, Vilma Dudonienè \\ Lietuvos sporto universitetas
}

\section{SANTRAUKA}

Tyrimo pagrindimas. Ropojimo raidos etapas kūdikystèje palengvina kūno padèties suvokimo vystymąsi, o vẻiau ir motorinių ịgūdžių vystymąsi, taip pat lavina atmintį, pagerina kognityvinę bei socialinę raidą (Xiong et al., 2018).

Tikslas - nustatyti vaikų motorinių gebejjimų ir kognityvinių funkcijų sąsajas su bendrosios motorikos ropojimo funkcija.

Metodai. 22 sveiki tiriamieji (4-6 metų vaikai), pagal tèvų pateiktos apklausos atsakymus, suskirstyti ị dvi grupes: nepraleidusius ir praleidusius ropojimo raidos etapą kūdikystejje. Visiems tiriamiesiems buvo vertintas funkcinis liemens stabilumas, pusiausvyra, koordinacija (šokinèjimas ìvairiomis kryptimis, kamuolio gaudymas ir kamuolio spyrimas) bei kognityvinès funkcijos.

Rezultatai. 85 proc. ropojusių vaikų turèjo funkciškai nestabilų liemenį, neropojusiųjų grupejje - 78 proc., skirtumas statistiškai reikšmingas. Kūdikystèje ropojimo nepraleidę vaikai pusiausvyrą bandè išlaikyti vidutiniškai tris kartus, ropojimą praleidę - 10 kartų $(\mathrm{p}<0,05)$. Vertindami koordinacinių gebejjimų užduočių atlikimą, nustatėme, kad tiek kūdikystèje ropojusių, tiek neropojusių vaikų šokinėjimo įvairiomis kryptimis ir kamuolio metimo koordinacija vertinama gerai, tačiau kamuolio spyrimo - patenkinamai. Ropojusių ( 89 proc.) ir neropojusių (78 proc.) vaikų dėmesio pastovumas vertinamas, atitinkamai - labai geras ir geras. Kūdikystėje nepraleidusių ropojimo vaikų raidos etapo grupeje, kamuolio gaudymas buvo tiesiogiai ir vidutiniškai stipriai susijęs su kamuolio spyrimo užduotimi $(\mathrm{r}=0,556 ; \mathrm{p}=0,048)$.

Išvados. Tiriamieji, kurie kūdikystejje praleido ropojimo raidos etapą, atsistojo anksčiau. Vaikai, nepraleidę ropojimo raidos etapo kūdikysteje, pasižymėjo geresne pusiausvyra, tačiau koordinaciniai gebẻjimai, funkcinis liemens stabilumas bei gebẻjimas koncentruoti dèmesį nesiskyrè nuo vaikų, kurie kūdikystejje praleido ropojimo funkciją

Raktažodžiai: vaikų motoriniai gebėjimai, kognityvinès funkcijos, ropojimas.

\section{IVADAS}

Normali ir nuosekli, atitinkanti chronologini amžių kūdikio motorinė raida iki vienerių metų yra labai svarbi tolesniam vaiko vystymuisi ir mokymuisi (Scharf, 2016). Teigiama (Pedrosa et al., 2015), kad ropojimo raidos etapas ypač svarbus kūdikio vystymuisi ir augimui, o kūdikystès laikotarpis nuo 7 iki 12 mèn.yra intensyviausias motorinių funkcijų lavėjimo periodas ir būtent šiuo laikotarpiu kūdikiai

Copyright (C) 2021 Silvija Urvikyte, Vilma Dudonienė. Published by Lithuanian Sports University.

This is an Open Access article distributed under the terms of the Creative Commons Attribution 4.0 International License, which permits unrestricted use, distribution, and reproduction in any medium, provided the original author and source are credited. 
pradeda ropoti (Zhang et al., 2019; Hadders-Algra, 2018). Ropojimas daro ịtaką ne tik kūdikio motoriniams gebejjimams, bet ir regejjimo lauko suvokimui, sąnariu stabilumui, erdvès suvokimui, socialiniams ịgūdžiams, akių-rankų koordinacijai, pilvo ir nugaros raumenų jègai, abiejų rankų judesių suderinamumui ir koordinacijai, propriorecepcijai bei smegenų veiklai (Graessle, 2018).

Tiek pirmieji vaiko gyvenimo metai, tiek priešmokyklinis amžiaus yra vienodai jautrūs ir svarbūs laikotarpiai: kūdikiams svarbus tuo, kad lavejja motorinès funkcijos, o ikimokyklinio amžiaus vaikams - pagrindiniai judesiai (True et al., 2017; Pennequin et al., 2010). Tačiau neaišku, ar šie laikotarpiai vienas su kitu susiję. Manome, kad vaikų, kurie kūdikysteje nepraleido bendrosios motorikos ropojimo etapo, motoriniai gebejjimai ir kognityvinès funkcijos turètų būti geresni nei vaikų, kurie kūdikysteje praleido ropojimo funkciją.

Tyrimo tikslas - nustatyti 4-6 metu vaikų motorinių gebejimų ir kognityviniu funkcijų sąsajas su bendrosios motorikos ropojimo funkcija kūdikystejje.

\section{TYRIMO METODAI}

Tiriamieji. Tyrime dalyvavo 22 sveiki 4-6 metų vaikai. Pagal tėvų pateiktus atsakymus apie ropojimo funkciją kūdikysteje, vaikai suskirstyti ị dvi grupes: $\mathfrak{i}$ vaikystejje ropojusių ir neropojusių vaikų grupes.

Tiriamujų atrankos kriterijai: gimę pilnai išnešioti (37-42 néštumo savaitę), sveiki vaikai, kurie neturi jokių sutrikimų, bei nelankę kineziterapijos procedūrų. Grupès buvo homogeniškos pagal tiriamųjų amžių, ūgị ir svorị (1 lentelè).

\section{1 lentelè. Tiriamųjų charakteristika}

\begin{tabular}{|c|c|c|c|c|c|}
\hline \multirow{2}{*}{ Grupė } & \multicolumn{2}{|c|}{ Imtis $(\mathrm{n}=22)$} & \multirow{2}{*}{$\begin{array}{l}\text { Amžius } \\
(m . \pm S N)\end{array}$} & \multirow{2}{*}{$\begin{array}{c}\text { Ūgis } \\
(\mathrm{cm} \pm \mathrm{SN})\end{array}$} & \multirow{2}{*}{$\begin{array}{c}\text { Svoris } \\
(\mathrm{kg} \pm \mathrm{SN})\end{array}$} \\
\hline & Mergaitès & Berniukai & & & \\
\hline Ropoję $(n=13)$ & 10 & 3 & $5,5 \pm 0,6$ & $115,9 \pm 6,5$ & $19,9 \pm 2,2$ \\
\hline Neropoję $(n=9)$ & 3 & 6 & $5,3 \pm 0,7$ & $115,1 \pm 8,7$ & $20,3 \pm 3,4$ \\
\hline
\end{tabular}

Tyrimo organizavimas. Tyrimas pradėtas gavus Lietuvos sporto universiteto Bioetikos komisijos leidimą atlikti biomedicininị tyrimą Nr. MNL-KIN(M)-2020-261 bei tėvų sutikimus. Suskirsčius vaikus ị grupes, buvo vertintas jų funkcinis liemens stabilumas, pusiausvyra ir koordinacija bei kognityvinès funkcijos.

Tyrimo metodai

Anketinė apklausa. Apklausos tikslas - sužinoti vaiko amžių, ar kūdikis gimė išnešiotas, sužinoti vaikų bendrosios motorikos raidą ir jų atsiradimo amžių. Ropojimas buvo traktuojamas, jei jis truko ne trumpiau nei du mèn. iki pradedant savarankiškai vaikščioti. Klausta, ar vaiko vystymosi metu buvo naudojamos pa- 
galbinès priemonès (vaikštynè, stumdukas) bei kaip patys tèvai vertina vaiko motorinius gebejjimus.

Antropometriniai matavimai. Matuotas tiriamujų ūgis $(\mathrm{cm})$ ir svoris $(\mathrm{kg})$.

Funkcinio liemens stabilumo ịvertinimas (Matthias testas). Šio testo tikslas ịvertinti vaiko gebejjimą išstovèti 30 sek. vertikalioje padètyje, kai rankos ištiestos i priekị $\left(90^{\circ}\right.$ kampas tarp liemens ir rankų), o dubuo neutralioje padètyje. Jei testo metu atliekami kompensaciniai judesiai: dubens pasvirimas pirmyn, juosmeninès stuburo dalies judesys pirmyn, krūtininès stuburo dalies - atgal, menčių ir rankų pakèlimas, registruojamas laikas, kada šie judesiai atliekami (Cudré-Mauroux et al., 2006).

Pusiausvyros ịvertinimas (testas „Flamingas“). Tiriamasis turejo kuo ilgiau išstovèti ant buomo dominuojančia koja sulenkus kitą koją, per kelio sąnarị ir prilaikant tos pačios pusès ranka. Padètį reikejjo išlaikyti 1 minutę, praradus pusiausvyrą, laikas buvo stabdomas ir testas tęsiamas tada, kai tiriamasis sugrịždavo ị pradinę padètį. Fiksuojamas bandymų (ne kritimų) išlaikyti pusiausvyrą skaičius (Zaqout et al., 2016).

Koordinacijos įvertinimas. Koordinacijai įvertinti buvo parinktos trys užduotys, remiantis Stambiosios motorikos vystymosi (angl. Test of Gross Motor Development TGMD-2) motorinių įgūdžių vertinimo testu. Buvo vertinamas tiriamujjų gebẻjimas šokinèti ịvairiomis kryptimis, gaudyti ir spirti kamuolị. Koordinacijos testo užduočių įverčiai: 0 balų - užduotis neatlikta nè karto; 1 balas - atlikta vieną kartą; 2 balai - atlikta du kartus (Ulrich, 2000).

Kognityvinių funkcijų ịvertinimas (Bourdon-Anfimov metodika). Šiuo testu vertinome dèmesio pastovumą ir koncentraciją. Tiriamiesiems pritaikytas figūrèlių testas, figūrèlès buvo sudètos lape, tiriamojo paprašyta išbraukti vèliavèles figūrų sekoje (Velea, Cojacaru, 2019). Testo rezultatas vertinamas pagal formulę, kuri apibrèžia dèmesio pastovumo ir koncentracijos vertę (Akvan, 2016; Eismont et al., 2001): $\mathrm{K}$ (proc.) $=((\mathrm{M}-\mathrm{O}) * 100) / \mathrm{n}$, kur $\mathrm{K}$ - vertė; $\mathrm{M}$ - bendras užbrauktų vèliavèliu skaičius, $\mathrm{O}$ - klaidingai pasirinktos figūrèlès, $\mathrm{n}$ - bendras vèliavėlių, kurias reikia išbraukti, skaičius. İverčio reikšmè vertinama lygiais: 81-100 proc. yra labai geras lygis, $61-80$ proc. - geras, $41-60$ proc. - vidutinis, $21-40$ proc. - blogas, 0-20 proc. - labai blogas.

Matematinè statistika. Tyrimo duomenų statistinè analizė atlikta naudojant „Microsoft Windows Excel 2015“ ir „SPSS 26.0“ programas. Duomenys pateikiami kaip aritmetinis vidurkis $(\overline{\mathrm{x}})$ ir standartinis nuokrypis $(\mathrm{SN})$. Kadangi duomenys nèra pasiskirstę pagal normalüj dèsnį, grupių palyginimas atliktas pagal neparametrinị Mann'o-Whitney'aus (U) kriterijų. Statistiškai reikšmingas skirtumas, kai $\mathrm{p}<0,05$. Rezultatai aprašomi pateikiant medianą, minimalią ir maksimalią reikšmę, aritmetinị vidurki - xme $(x m i n-x m a x ; ~ \bar{x})$. Atlikta koreliacinè analizė pagal 
Spirmeno koreliacijos koeficientą, kuris skirstomas ị silpną $(|\mathrm{r}|<0,2)$, vidutinị $(0,2$ $\leq|r| \geq 0,6)$ arba stiprų ( $|r|>0,6)$ ryši (Prion, Haerling, 2014). Grafikuose duomenys pateikiami kaip aritmetinis vidurkis $(\times)$ ir mediana $(-)$.

\section{TYRIMO REZULTATAI}

Anketinė apklausa ir ankstyvosios motorinès raidos nustatymas. Dauguma tėvų, savo vaikų, tiek praleidusių (56 proc.), tiek nepraleidusių (69 proc.) ropojimo raidos etapą, motorinius gebejjimus vertino puikiai, tarp tėvų vertinimų reikšmingų skirtumų nenustatyta $(U=47 ; p=0,346)$.

\section{3 lentelè. Anketinès apklausos duomenys}

\begin{tabular}{|l|l|l|l|l|l|}
\hline Tiriamoji grupé & $\begin{array}{c}\text { Ar šliau- } \\
\text { žiojo? } \\
\text { Taip/Ne } \\
\text { (proc.) }\end{array}$ & $\begin{array}{c}\text { Kada } \\
\text { pradėjo } \\
\text { ropoti? } \\
\text { (mèn. } \pm \\
\text { SN) }\end{array}$ & $\begin{array}{c}\text { Kada } \\
\text { atsistojo? } \\
\text { (mén.) } \\
\text { (mén. } \pm \\
\text { SN) }\end{array}$ & $\begin{array}{c}\text { Kokio am- } \\
\text { žiaus kūdi- } \\
\text { kis pradėjo } \\
\text { savarankiš- } \\
\text { kai vaikš- } \\
\text { čioti? } \\
\text { (mén. } \pm \\
\text { SN) }\end{array}$ & $\begin{array}{c}\text { Ar kūdi- } \\
\text { kystėje } \\
\text { naudotos } \\
\text { pagalbinės } \\
\text { priemonés? } \\
\text { Taip/Ne } \\
\text { (proc.) }\end{array}$ \\
\hline Ropojusieji $(\mathrm{n}=13)$ & $85 / 15$ & $7,5 \pm 0,9$ & $10,2 \pm 1,1$ & $12,6 \pm 1,6$ & $38 / 62$ \\
\hline Neropojusieji $(\mathrm{n}=9)$ & $22 / 78$ & - & $8,7 \pm 1,9$ & $11,3 \pm 1,3$ & $67 / 33$ \\
\hline Tarp grupiu & $\mathrm{p}=0,004$ & - & $\mathrm{p}=0,011$ & $\mathrm{p}=0,158$ & $\mathrm{p}=0,204$ \\
\hline
\end{tabular}

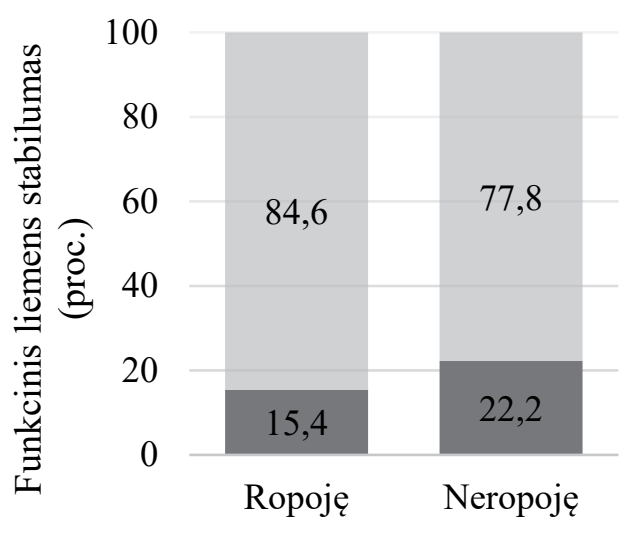

च Išlaikè $\quad$ Neišlaikè 


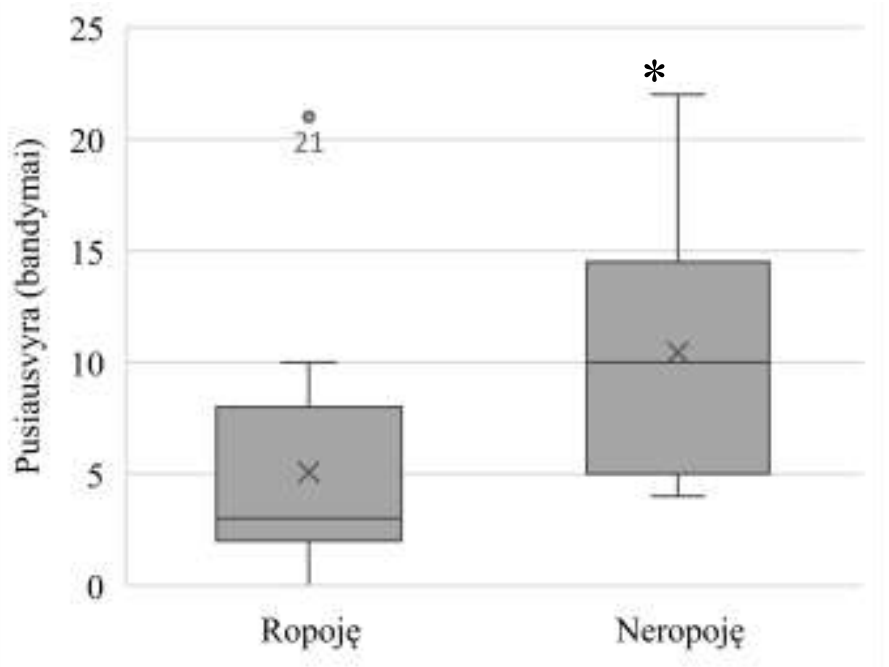

\section{3 pav. Tiriamųjų, kūdikystėje ropojusių ir neropojusių pusiausvyra; * $-\mathbf{p}<0,05$ palyginus tarp grupių}

Liemens funkcinis stabilumas. Vertinant tiriamųjų funkcinį liemens stabilumą, nustatyta, kad didžioji dauguma vaikų tiek kūdikystejje ropojusių, tiek neropojusių $(\mathrm{U}=55 ; \mathrm{p}=0,690)$ negebejjo išstovèti $30 \mathrm{~s}$ ir išlaikyti funkcinio stabilumo testo (2 pav.).

Pusiausvyros ir koordinacijos vertinimas. Vertinant statinę tiriamujjų pusiausvyrą, nenustatyta reikšmingų skirtumų $(U=21 ; p=0,011)$ tarp kūdikysteje ropojusių ir neropojusių vaikų (3 pav.). Nė vienas tiriamasis, mėginęs išlaikyti pusiausvyrą, neviršijo 30 kartų, todèl pagal tyrëjų pateiktas rekomendacijas, galime teigti, jog tiriamujų pusiausvyra buvo gera (Groselj et al., 2019).

Vertinant koordinacinių gebejjimų užduočių (šokinejjimas ịvairiomis kryptimis, kamuolio gaudymas ir spyrimas) atlikimą, nustatyta, kad tiek kūdikysteje ropojusių ir neropojusių vaikų šokinèjimo įvairiomis kryptimis ir kamuolio metimo koordinacija vertinama gerai, tačiau kamuolio spyrimo - patenkinamai. Tarp grupių nebuvo statistiškai reikšmingų skirtumų ( $\mathrm{p}>0,05)$ (4 lentelè).

Kognityvinių funkcijų vertinimas. Kūdikystejje ropojusiųjų vaikų dèmesio pastovumo ir koncentracijos vertès lygis buvo įvertintas kaip labai geras, neropojusiųjų lygis - geras, tačiau tarp grupių nėra statistiškai reikšmingo skirtumo ( $\mathrm{U}=$ $42 ; \mathrm{p}=0,247)$.

Sąsajos tarp vertintų rodiklių ir bendrosios motorikos ropojimo raidos etapo. Vertinant sąsajas tarp ropojimo raidos etapo ir tyrime vertintų rodiklių (funkcinio 
liemens stabilumo, motorinių gebejimų, kognityvinių funkcijų), nustatyta tiesioginè vidutinio stiprumo reikšminga sąsaja $(r=0,556 ; p=0,048)$ tarp šių koordinacinių gebejjimų: kamuolio spyrimo ir kamuolio gaudymo.

4 lentelè. Kūdikystèje ropojusių ir neropojusių koordinacinių gebẻjimų vertinimas

\begin{tabular}{|c|c|c|c|c|c|}
\hline \multirow{3}{*}{$\begin{array}{c}\text { Taškai } \\
\text { gauti už } \\
\text { užduotị }\end{array}$} & \multicolumn{4}{|c|}{ Grupès } & \multirow{3}{*}{$\begin{array}{c}\text { U reikšmè; } \\
\text { p lygmuo }\end{array}$} \\
\hline & \multicolumn{2}{|c|}{ Ropoję $(n=13)$} & \multicolumn{2}{|c|}{ Neropoję $(n=9)$} & \\
\hline & n (proc.) & $\mathbf{x}_{\operatorname{me}}\left(\mathbf{x}_{\min }-\mathbf{x}_{\max } ; \overline{\mathbf{x}}\right)$ & n (proc.) & $\mathbf{x}_{\operatorname{me}}\left(\mathbf{x}_{\min }-\mathbf{x}_{\max } ; \overline{\mathbf{x}}\right)$ & \\
\hline \multicolumn{6}{|c|}{ Šokinèjimas įvairiomis kryptimis } \\
\hline 0 taškų & $0(0,0)$ & \multirow{3}{*}{$2(1-2 ; 1,92)$} & $0(0,0)$ & \multirow{3}{*}{$2(1-2 ; 1,89)$} & \multirow{3}{*}{$\begin{array}{l}\mathrm{U}=57 \\
\mathrm{p}=0,789\end{array}$} \\
\hline 1 taškas & $1(8,0)$ & & $1(11,0)$ & & \\
\hline 2 taškai & $12(92,0)$ & & $8(89,0)$ & & \\
\hline \multicolumn{6}{|c|}{ Kamuolio metimas ị viršų ir pagavimas } \\
\hline 0 taškų & $0(0,0)$ & \multirow{3}{*}{$1(1-2 ; 1,46)$} & $2(22,0)$ & \multirow{3}{*}{$2(0-2 ; 1,33)$} & \multirow{3}{*}{$\begin{array}{l}\mathrm{U}=57 \\
\mathrm{p}=0,911\end{array}$} \\
\hline 1 taškas & $7(54,0)$ & & $2(22,0)$ & & \\
\hline 2 taškai & $6(46,0)$ & & $5(56,0)$ & & \\
\hline \multicolumn{6}{|c|}{\begin{tabular}{|l|} 
Kamuolio spyrimas \\
\end{tabular}} \\
\hline 0 taškų & $1(7,0)$ & \multirow{3}{*}{$1(0-2 ; 1,31)$} & $3(33,0)$ & \multirow{3}{*}{$1(0-2 ; 0,89)$} & \multirow{3}{*}{$\begin{array}{l}\mathrm{U}=41 \\
\mathrm{p}=0,189\end{array}$} \\
\hline 1 taškas & $7(54,0)$ & & $4(44,0)$ & & \\
\hline 2 taškai & $5(39,0)$ & & $2(23,0)$ & & \\
\hline
\end{tabular}

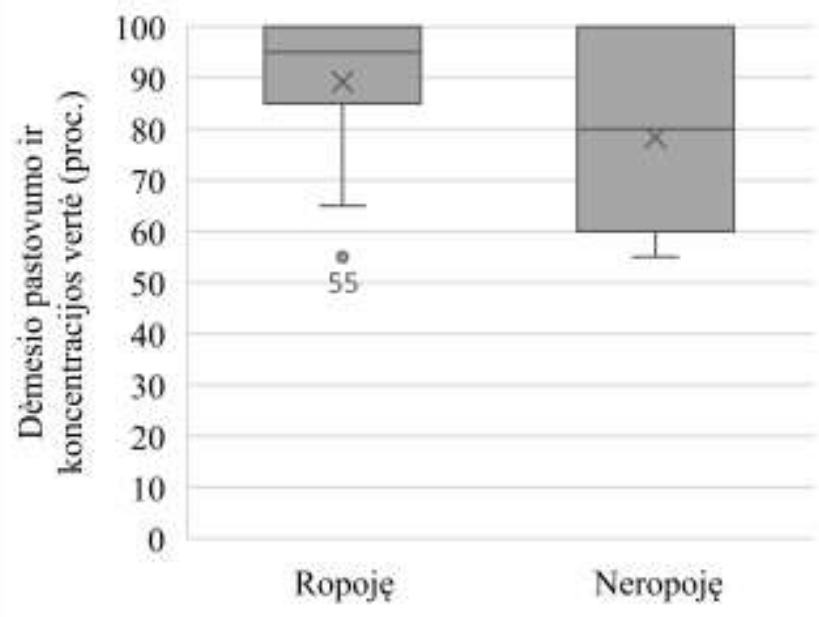

4 pav. Tiriamųjų, kūdikystèje ropojusių ir neropojusių, dẻmesio pastovumas ir koncentracija 


\section{DISKUSIJA}

Tyrime buvo siekiama nustatyti vaikų motorinių gebejjimų ir kognityvinių funkcijų sąsajas su bendrosios motorikos ropojimo funkcija. Vertinome vaikų, praleidusių ir nepraleidusių kūdikystès bendrosios motorikos ropojimo raidos etapo, funkcinį liemens stabilumą, pusiausvyrą, koordinacinius gebejjimus bei gebejjimą koncentruoti dèmesį.

Mūsų tyrime, apklausus tèvus (globèjus) apie vaikų motorinès raidos patirtị kūdikystèje, paaiškèjo, kad šliaužimo raidos etapas kūdikystèje ir atsistojimo amžius tarp ropojusiujų ir praleidusių ropojimo raidos etapą kūdikystėje vaikų skyrèsi statistiškai reikšmingai. Tyrẻjai pabrèžia, kad tėvų vertinimas yra pirminis rodiklis, kuris nusako, ar reikia išsamiau tirti vaiką (Zysset et al., 2018). Mūsų tyrime dauguma tèvų savo vaikų, tiek praleidusių (56 proc.), tiek nepraleidusių (69 proc.) ropojimo raidos etapo, motorinius gebejimus įvertino puikiai, statistiškai reikšmingų skirtumų nenustatyta.

A. Zysset et al. (2018) tyrime buvo palyginti tèvų atsakymai apie jų priešmokyklinio amžiaus vaikų motorinius gebejjimus (pvz., šokinèjimas įvairiomis kryptimis, kamuolio metimas, pusiausvyra) su standartizuotų testų norminiais rodikliais, rezultatai parodė, kad koreliacinis ryšys tarp tėvų atsakymų ir testo rezultatų buvo silpnas, toks pat ryšys nustatytas ir mūsų tyrime.

Nustatėme, kad tiek kūdikystėje ropoję, tiek neropoję vaikai, vertinant funkcinį liemens stabilumą ,Matthias“ testu, pademonstravo panašius rezultatus: kompensacinius judesius atliko 85 proc. kūdikystejje ropojusių ir 78 proc. kūdikystèje neropojusių vaikų. Panašius rezultatus pateikè ir Brzęk et al. (2017) tyrime, kuriame buvo vertinta ankstyvojo mokyklinio amžiaus vaikų laikysena ir nustatyta, kad funkcinis liemens nestabilumas būdingas net 70 proc. vaikų.

Mūsų tyrime vaikai, nepraleidę bendrosios motorikos ropojimo raidos etapo, mažiau kartų bande išlaikyti pusiausvyrą, palyginus su vaikais, praleidusiais ropojimo raidos etapą, skirtumas statistiškai reikšmingas. V. Sember et al. (2020) tyrimo duomenimis „Flamingo“ testas turi stiprų ryšį su kitais motorinio gebejjimo testais, tokiais kaip èjimas, bėgimas, šokinèjimas, tačiau mūsų tyrime koreliaciniai ryšiai su pasirinktais motoriniais gebejjimais buvo silpni. M. Radžiūnienès (2016) tyrimo rezultatai taip pat parodè, kad 6-7 metų amžiaus vaikai, kuriems kūdikystejje buvo diagnozuotas specifinis motorinès raidos sutrikimas, pademonstravo prastesnius pusiausvyros rezultatus nei vaikai, kuriems šis sutrikimas nebuvo diagnozuotas.

Koordinaciniams gebejjimams įvertinti buvo pasirinktos 3 užduotys, tokios kaip šokinejjimas ịvairiomis kryptimis, kamuolio gaudymas ir kamuolio spyrimas. Visų vertintų užduočių rezultatai tarp grupių (ropojusių ir praleidusių ropojimą) neparodẻ statistiškai reikšmingo skirtumo. M. Visser ir D. Franzsen (2010) savo 
tyrime tyre akių-rankų koordinaciją tarp vaikų, praleidusių ir nepraleidusių ropojimą, pagal DTVP-2 (Development Test of Visual Perception) testą, kurio metu buvo taikyta pieštuko sugriebimo ir jo valdymo užduotis. Šių tyrejų gauti rezultatai tarp grupių statistiškai reikšmingo skirtumo taip pat neparodè (Visser \& Franzsen, 2010).

Vertinant mūsų tiriamujų kognityvines funkcijas tarp vaikų, nepraleidusių ropojimo raidos etapo, ir tų, kurie praleido, pastebeta tendencija, kad kūdikystejje ropojusiujų dėmesio pastovumas ir koncentracija yra geresnè, tačiau skirtumas nèra statistiškai reikšmingas. Analizuojant mokslinę literatūrą apie kūdikystejje turètą motorinę patirtị ir jos ịtaką vẻlesnei kognityvinei raidai, nustatyta, kad kūdikystejje nepraleidę motorinès raidos etapų, 3-5 metų vaikai pasižymėjo geresniu kalbos žodynu, o septynerių metų sulaukę vaikai - geresniais skaitymo igūdžiais (Viholainen et al., 2006).

Tyrime, tik kūdikysteje ropojusiujų grupeje, nustatyta vidutinio stiprumo reikšminga sąsaja tarp dviejų koordinacinių gebejjimų - tai kamuolio gaudymo ir kamuolio spyrimo. Galime daryti prielaidą, kad neropojusiųju grupèje šie koordinaciniai gebejjimai nebuvo pakankamai išlavinti.

Galima daryti prielaidą, kad galbūt toks rezultatų pasiskirstymas yra dèl mažos imties tiriamųjų, todèl ateityje vertètų tyrimą pakartoti ne tik su didesne tiriamųu imtimi, bet ir pasirinkus daugiau instrumentinių testų.

\section{IŠVADOS}

Tiriamieji, kurie kūdikystejje praleido ropojimo raidos etapą, anksčiau atsistojo. Ropojimo raidos etapas yra glaudžiai susijęs su šliaužimo raidos etapu, nes didžioji dauguma (85 proc.) ropojusiųjų nepraleido šliaužimo raidos etapo. Vaikai, kūdikystejje nepraleidę bendrosios motorikos raidos ropojimo etapo, pasižymėjo geresne pusiausvyra, tačiau koordinaciniai gebejjimai, funkcinis liemens stabilumas bei gebėjimas koncentruoti dẻmesį nesiskyrè nuo tụ vaikų, kurie kūdikystėje praleido bendrosios motorikos raidos ropojimo etapą. Nustatyta tiesiogine vidutinio stiprumo reikšminga sąsaja tarp kamuolio gaudymo ir kamuolio spyrimo, ropojimo raidos etapo nepraleidusių vaikų grupeje.

Finansavimo šaltinio deklaracija - finansavimo nèra.

Interesų atskleidimas - nèra. 


\section{LITERATŪRA}

Akvan, O. (2016). Bourdon Test Online. Interactive Portal-Book of Methods of Self-Development and Achieving Success. Internetinè prieiga: https://metodorf.com/tests/bourdon test.php

Brzęk, A., Dworrak, T., Strauss, M., et al. (2017). The weight of pupils'schoolbags in early school age and its influence on body post

ure. BMC musculoskeletal disorders, 18 (1), 1-11. Doi: 10.1186/s12891-017-1462-z.

Cudré-Mauroux, N., Kocher, N., Bonfils, R., \& Pirlet, M. (2006). Relationship between impaired functional stability and back pain in children. Swiss medical weekly, 136 (4546).

Eismont, E. V., Kaida, A. I., \& Bakunova, A. V. (2001). The relationship between the eeg indices and levels of development of voluntary attention in the children aged 5-9. Int. J. Psychophysiol, 39 (2-3), 197-103.

Graessle, E. (2018). Infant crawling orthosis and home program to strengthen a neurologically impaired upper extremity. Journal of Hand Therapy; 31 (3), 411-415. Doi: 10.1016/j.jht.2017.05.014.

Groselj, J., Osredkar, D., Sember, V., Pajek M. (2019). Associations between balance and other fundamental motor skills in pre-adolescents. Medicina dello sport, 72, 200-215. Doi: $\underline{10.23736 / \text { S0025-7826.19.03482-3 }}$.

Hadders-Algra, M. (2018). Neural substrate and clinical significance of general movements: an update. Developmental Medicine \& Child Neurology, 60 (1), 39-46. Doi: 10.1111/dmcn.13540.

Pedrosa, C., Caçola, P., \& Carvalhal, M. I. M. M. (2015). Factors predicting sensory profile of 4 to 18 month old infants. Revista Paulista de Pediatria (English Edition), 33 (2), 160-166. Doi: 10.1016/j.rpped.2014.11.016.

Pennequin, V., Sorel, O., \& Fontaine, R. (2010). Motor planning between 4 and 7 years of age: Changes linked to executive functions. Brain and cognition, 74 (2), 107-111. Doi: 10.1016/j.bandc.2010.07.003.

Prion, S., \& Haerling, K. A. (2014). Making Sense of Methods and Measurement: Spearman-Rho Ranked-Order Correlation Coefficient. Clinical Simulation in Nursing, 10 (10), 535-536. Doi: 10.1016/j.ecns.2014.07.010.

Radžiūnienè, M. (2016). Motorikos pokyčiai kūdikystèje ir vaikystèje, taikant pagal amžių adaptuotą judesių mokymą: daktaro disertacija: biomedicinos mokslai, visuomenès slauga (10B).

Scharf, R. J., Scharf, G. J., \& Stroustrup, A. (2016). Developmental Milestones. Pediatrics in review, 37 (1), 25. Doi: $10.1542 /$ pir.2014-0103.

Sember, V., Grošelj, J., \& Pajek, M. (2020). Balance Tests in Pre-Adolescent Children: Retest Reliability, Construct Validity, and Relative Ability. International Journal of Environmental Research and Public Health, 17 (15), 5474. Doi: 10.3390/ijerph17155474.

True, L., Pfeiffer, K. A., Dowda, M., et al. (2017). Motor competence and characteristics within the preschool environment. Journal of science and medicine in sport, 20 (8), 751-755.

Ulrich, D. A. (2000). Test of Gross Motor Development, Examiner's manual. Pro-ED. Inc., Austin, Texas.

Velea, T. \& Cojacaru, V. (2019). The effect of playing chess on focused attention. ICPESK 2018 International Congress of Physical Education, Sports and Kinetotherapy. Education and Sports Science in the 21st Century, Edition dedicated to the 95th anniversary of UNEFS. The European Proceedings of Social \& Behavioural Sciences. https://dx.doi.org/10.15405/epsbs.2019.02.84

Viholainen, H., Ahonen, T., Lyytinen, P., et al. (2006). Early motor development and later language and reading skills in children at risk of familial dyslexia. Developmental Medicine \& Child Neurology, 48 (5), 367-373. Doi: $10.1017 / \mathrm{S} 001216220600079 \mathrm{X}$.

Visser, M. M., \& Franzsen, D. (2010). The association of an omitted crawling milestone with pencil grasp and control in five-and six-year-old children. South African Journal of Occupational Therapy, 40 (2), 19-23.

Xiong, Q. L., Hou, W. S., Xiao, N., et al. (2018). Motor skill development alters kinematics and co-activation between flexors and extensors of limbs in human infant crawling. IEEE Transactions on Neural Systems and Rehabilitation Engineering, 26 (4), 780-787. Doi: 10.1109/TNSRE.2017.2785821.

Zaqout, M., Michels, N., Bammann, K. C., et al. (2016). Influence of physical fitness on cardio-metabolic risk factors in European children. The IDEFICS study. International journal of obesity, 40 (7), 1119-1125.

Zhang, L., Deng, C. F., Xiong, Q. L., et al. (2019, July). Analysis of the Inter-Joints Synergistic Patterns of Limbs in Infant Crawling. Frontiers in neurology, 9, 869. Doi: 10.3389/fneur.2018.00869.

Zysset, A. E., Kakebeeke, T. H., Messerli-Bürgy, N., et al. (2018). The validity of parental reports on motor skills performance level in preschool children: a comparison with a standardized motor test. European journal of pediatrics, 177 (5), 715-722. Doi: 10.1007/s00431-017-3078-6. 


\section{RELATIONSHIP BETWEEN CRAWLING FUNCTION \\ IN INFANCY AND MOTOR SKILLS, COGNITIVE FUNCTIONS \\ IN 4 TO 6-YEAR-OLD CHILDREN}

\section{Silvija Urvikytė, Vilma Dudonienė}

Lithuanian Sports University

\section{ABSTRACT}

Background. The developmental stage of crawling in infancy facilitated the development of body position perception and of motor skills later in life, as well as memory development, improved cognitive and social development (Xiong et al., 2018).

Aim. To determine relationship between children's motor skills and cognitive functions with motor skills crawling function.

Methods. 22 healthy subjects (aged 4-6 years old) were divided into two groups based on the answers of a survey provided by parents: those who did not skip and skipped crawling stage in infancy. All subjects were assessed for trunk functional stability, balance, coordination (multi-directional jumping, ball catching and kicking), and cognitive function.

Results. Statistically significant difference was observed with $85 \%$ of crawlers having a functionally unstable trunk, thus in the group of non-crawlers $-78 \%$ have a functionally unstable trunk. Subjects who did not skip the crawling stage in infancy tried to maintain the balance 3 times on average, those who did not crawl10 times on average $(\mathrm{p}<0.05)$. Assessing the performance of coordination skills tasks, study found that the coordination of both crawler and non-crawler group jumping in different directions and throwing the ball was assessed as good, however kicking of the ball was evaluated as average. Crawler (89\%) and non-crawler $(78 \%)$ ability to focus attention rated as very good and good accordingly. In group of infants who did not miss crawling stage ball catching is directly and moderately strongly coherent to the task of kicking the ball $(\mathrm{r}=0.556 ; \mathrm{p}=0.048)$.

Conclusions. Subjects who skipped the crawling stage stood up earlier. Children who did not skip the crawling stage in infancy showed a better balance, however coordination skills, trunk functional stability and ability to concentrate attention did not differ from children who missed crawl stage in infancy.

Keywords: children's motor skills, cognitive functions, crawling.

Gautas: 2021-04-28

Priimtas: 2021-05-24 